\title{
Design of New Normal Health Protocol Reminder Using Arduino Nano and Ultrasonic Sensor
}

\author{
Dwi Hastuti \\ Department of Electrical Engineering \\ University of PGRI Adi Buana Surabaya \\ dwi.hastuti@unipasby.ac.id
}

\author{
M. Rizqi Zulkarnain \\ Department of Electrical Engineering \\ University of PGRI Adi Buana Surabaya \\ zulkarnainmrizqi@gmail.com
}

Abstract - Corona virus is a group of viruses that can cause disease in animals or humans. The most common symptoms of COVID-19 are fever, dry cough and feeling tired. Other symptoms that some patients may experience less often include aches and pains, nasal congestion, headache, conjunctivitis, sore throat, diarrhea, loss of taste or smell, rash on the skin, or discoloration of fingers or toes. The Indonesian government urges the public to maintain productivity even in the midst of the ongoing corona virus pandemic with a new order called the new normal, namely by implementing health protocols. PGRI Adi Buana University Surabaya is one of the places where many people do their activities and gather. The existence of this gathering activity can increase the risk of transmitting COVID19. To prevent transmission, every academic community must always apply the new normal health protocol as recommended by the government, such as wearing masks, washing hands with soap, and maintaining social distancing. So far, health protocol surveillance activities in the campus environment have only relied on the role of security so that it is less effective considering the limited human ability, so a tool is needed to always remind in implementing the new normal health protocol. The tool is in the form of audio using the Ultrasonic HC-SR04 and Arduino Nano sensors. So every object that passes through the sensor will be processed by a microcontroller (Arduino Nano) and then processed into an output in the form of a buzzer. The buzzer that comes out is a voice to remind everyone in the university to implement health protocols.

Keywords - Corona Virus, New Normal, Arduino Nano, Ultrasonic HC-SR04, Buzzer

\section{INTRODUCTION}

Indonesia is one of the countries in the ASEAN region with the most patients who have been confirmed positive for Covid-19. According to media data from Kompas and CNN Indonesia, from the time the first case was discovered in March 2019 to this October, positive patients have reached 350 thousand people. This shows that the level of the spread of Covid-19 in Indonesia is still high. This virus can spread mainly from person to person through droplets from the nose or mouth that come out when a person infected with Covid-19 coughs, sneezes or talks. These splashes are relatively heavy, they do not travel far and fall to the ground quickly. People can become infected with Covid-19 if they breathe in the splash of an infected person. These splashes can also stick to objects and other surfaces around people such as tables, door handles, and handrails. People can become infected by touching these objects or surfaces, then touching their eyes, nose or mouth.

The government is trying to suppress the spread of the Covid-19 virus by urging the public to implement the New Normal health 
protocol, which is new habits and behaviors based on adaptation to cultivate clean and healthy living habits. This is done by regularly washing your hands regularly with soap and clean running water, or cleaning them with an alcohol-based antiseptic, wearing a mask when leaving the house, keeping a safe distance and avoiding crowds.

Anyone who is active in public places, workplaces, schools and places of worship must always pay attention to this health protocol. Community discipline control must always be in place to suppress the spread of this virus. Including in the environment of the PGRI ADI Buana Surabaya University itself. To support government programs in reducing the spread of the corona virus and implementing current health protocols in the PGRI Adi Buana University environment, it relies on the role of security and by posting slogans. This has not been fully effective in ensuring the academic community in the campus environment in implementing health protocols considering the limited number and ability of officers.

For this reason, a tool is needed to remind and assist the role of security so that the academic community on campus always applies a clean lifestyle. The tool uses the Arduino Nano system which can process data from the HC-SR04 Ultrasonic sensor into a buzzer in the form of commands to implement the New Normal health protocol. This tool is expected to be able to remind and also as a self-reminder, in implementing health protocols so that the limitations of officers to control discipline can be helped, so that later it is hoped that awareness of implementing health protocols can also grow from each other.

\section{METHODS}

\section{A. Electricity}

In modern life, the presence of electric power is felt to be very important, because electricity is very useful as a source of energy. Almost all machines used in everyday life, both in households and in industry, mostly use electricity. The use of this energy can be seen directly in households, schools, hospitals and industries.

Electrical energy has several advantages over other energy, including:

a. Easier to distribute

b. Easier to distribute over a wider area

c. It is easier to convert it into other forms of energy, such as heat, light, sound or mechanical power.

Electricity is expressed in a quantity, namely:

$\mathrm{V}=\mathrm{I} \times \mathrm{R}$

Where :

$\mathrm{V}$ : Voltage (volts)

I: Current (A)

$\mathrm{R}$ : Resistance (Ohm)

Electric current (Ampere units) is illustrated as the flow of water coming out of a tap, while the water level is illustrated by the electric voltage level (units of Volt) and the diameter of the tap is illustrated as a resistance value (Ohm units). If the resistance value is small, the current flowing is large, conversely, if the resistance value is large, the current flowing is small. But this also depends on the voltage level, the greater or the higher the voltage level, the current flowing will be greater than the current flowing when the voltage level is low.

In a circuit (load / load) with a closed power supply source, generally electricity is seen as flowing from a positive voltage source (source $/ \mathrm{V}+$ ) the power supply enters the circuit and the electricity leads to a negative voltage source (Ground). When the power supply source is open, the electricity will stop.

B. B. Microcontroller

The microcontroller in an electronic circuit functions as a controller that regulates the work process of the electronic circuit. 
Inside a microcontroller IC there is a CPU, memory, timer, serial and parallel communication channels, input / output ports, $\mathrm{ADC}$, and others. Arduino is an open source microcontroller board, where the schematic and PCB design are open source. This device is intended for anyone interested in using a microcontroller in a practical and easy way. For beginners, using this board will find it easy to learn control with a microcontroller, for controller designers it will be easier to make prototypes or implementations.

Arduino can be used to detect the environment by receiving input from various sensors, for example: light, temperature, infrared, ultrasonic, distance, pressure, humidity and can control surrounding equipment. There are various types of Arduino, some of which are on the market, including: Arduino UNO, Arduino Duemilanova, Arduino Leonardo, Arduino Nano, Arduino Mega 2560 / Mega ADK, Esplora, Micro, and others. Each type of Arduino has different shapes and E. characteristics. This difference can be used by users to use the type of Arduino that suits their needs.

\section{Ultrasonic sensor hc-sr04}

The HC-SR04 is an ultrasonic sensor module that can measure distances ranging from $2 \mathrm{~cm}$ to $4 \mathrm{~m}$. In this module there is an ultrasonic transmitter, receiver, and control circuit. Ultrasonic sensors work by emitting a wave and then calculating the time the wave reflects. Ultrasonic waves work at frequencies ranging from $20 \mathrm{KHz}$ to $20 \mathrm{MHz}$.

The ultrasonic sensor consists of a 40 $\mathrm{KHz}$ signal generator chip, an ultrasonic speaker, and an ultrasonic microphone. The ultrasonic speaker converts the $40 \mathrm{KHz}$ signal into sound while the ultrasonic microphone detects the sound reflection. The ultrasonic sensor will send ultrasonic sound when there is a trigger pulse from the microcontroller.
Ultrasonic sound with a frequency of $40 \mathrm{KHz}$ will be emitted for 200 Us. This sound will travel through the air at a speed of $340 \mathrm{~m} / \mathrm{s}$ or 29,412 Us every $1 \mathrm{~cm}$, hitting objects and will be reflected back to the ultrasonic sensor.

\section{D. Resistor}

Resistors or resistance are the most widely used electronic components in any electronics project. Resistor is actually more accurately defined as resistance, not as resistance. Because in its work, the resistor does not hold the electric current. But the opposite is the resistor against the electric current, so the electric power will decrease when it passes through this component. Resistors or in Dutch called weerstand, are generally used in electronic circuits related to electric currents, for example to reduce voltage / current, divide voltage, and others. Resistor prices are expressed in ohms, while resistor resistance is measured in Watts.

\section{E. Buzzer}

In a circuit or equipment that requires sound indicators such as anti-theft alarms, reverse warning signs on cars or trucks and house bells, an electronic component that is capable and has this function is needed. Compared to using a loud speaker, a component that is relatively cheaper and easier to use is needed, namely the Electronic Buzzer.

Buzzer Electronics is an electronic component that can produce sound vibrations in the form of sound waves. Electronic buzzer will produce sound vibrations when given a certain amount of voltage according to the shape and size specifications of the electronic buzzer itself. In general, this electronic buzzer is often used as an alarm because its use is quite easy, namely by providing an input voltage, the electronic buzzer will produce sound vibrations in the form of sound waves that can be heard by humans. 


\section{RESULTS AND DISCUSSION}

The analytical method used is experimental analysis, to analyze the accuracy of the tool through the appropriate components after the measurement test is carried out. Besides that, descriptive analysis is used to describe the results of the experiment through:

a. Use of a suitable microcontroller, which is used to read the input from the sensor.

b. Testing each component to ensure that all components work normally.

c. Making programs to run Arduino devices

\section{CONCLUSION}

Below is a picture of the finished product and is ready for testing to ensure that the tool can work as expected. Preliminary testing is carried out on each component to reduce the risk of tool failure. This is done so that if there is an error in installing the components or the output is not what you want, the components can be replaced immediately. After making sure all the components are in good condition, then proceed with testing the tool. Connect the Arduino nano with a DC $5 \mathrm{~V}$ voltage source, and the Arduino lamp lights up indicating the tool is working.

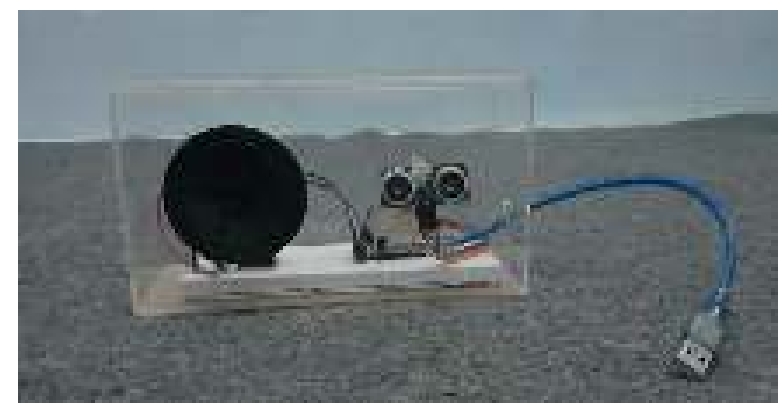

From the measurement results, the components of the research tool can conclude the product results, namely: a. The power supply circuit can turn on components that require a voltage source such as Arduino.

b. The ultrasonic sensor can read obstacles that pass through the sensor

c. Buzzer can sound according to the program being made.

Then the tool testing is carried out at the house gate, with variations in the testing distance. After that, measurements and analysis of the results of the application design tool are carried out to determine how far the sensor can detect objects for Arduino to process and output in the form of a buzzer. Tests were carried out on several variations of the distance including $50 \mathrm{~cm}, 60 \mathrm{~cm}, 100 \mathrm{~cm}$, $150 \mathrm{~cm}$. The sensor test results are shown in the table below:

\begin{tabular}{|l|c|c|}
\hline NO & Object & Distance Description \\
\hline 1 & $50 \mathrm{~cm}$ & Beep \\
\hline 2 & $60 \mathrm{~cm}$ & Beep \\
\hline 3 & $100 \mathrm{~cm}$ & Beep \\
\hline 4 & $150 \mathrm{~cm}$ & Not beep \\
\hline
\end{tabular}

Based on the results of the above data analysis from the per-component test, it shows that the components can work well and according to what is desired. Whereas for testing the whole tool can work according to what you want, namely the design can give orders to remind the Covid-19 health protocol, namely wearing masks, washing hands, and maintaining distance. The command is given in the form of a sound issued by the buzzer from the sensor detection results and Arduino processing.

\section{REFERENCES}

[1] Andrianto, Heri., Darmawan, Aan. (2017). Arduino Belajar Cepat dan Pemrograman. Bandung: Informatika.

[2] Bishop, Owen., (2002). Dasar-Dasar Elektronika. Jakarta: Erlangga. 
[3] Fajar Wicaksono, Mochammad., (2019). Aplikasi Arduino dan Sensor. Bandung: Informatika

[4] Noersasongko, Wahyu BS., (2002). Pedoman Dasar Elektronika Untuk Pemula. Pekalongan: CV Gunung Mas.

[5] Tim Fakultas Teknik., (2020). Pedoman Tugas Akhir Fakultas Teknik. Universitas PGRI Adi Buana Surabaya

[6] Kemenkes RI. (2020). Pertanyaan dan Jawaban Terkait COVID-19 Kementerian Kesehatan. Retrieved from https://covid19.kemkes.go.id.

[7] Kemenkes RI. (2020). Protokol Penanganan COVID-19 di Area Institusi Pendidikan. Retrieved from infeksiemerging.kemkes.go.id

[8] Gugus Tugas Percepatan Penanganan Covid. (2020). Penyesuaian Kebijakan Pembelajaran di Masa Pandemi COVID-19. Retrieved from https://covid19.go.id

[9] Gugus Tugas Percepatan Penanganan Covid. (2020). Info Berita Seputar Virus Corona. Retrieved from www.covid19.go.id.

[10] Asmara, Chandra Gian. (2020). Apa Itu New Normal \& Bagaimana Protokolnya. Retrieved from www.cnbcindonesia.com

[11] Wikipedia (2020). Koronavirus. Retrieved from https://id.wikipedia.org/wiki/Koronavir us. 